\title{
Clients' Perspectives of Risk Management Practice in Malaysian Construction Industry
}

\author{
Norazian Mohd Yusuwan, Hamimah Adnan \& Ahmad Faris Omar \\ Department of Quantity Surveying \\ Faculty of Architecture, Planning and Surveying \\ University Teknologi MARA, Shah Alam, Malaysia
}

Tel: 60-3-5544-4935_E-mail: hamimah689@salam.uitm.edu.my

\author{
Hj. Kamaruzaman, Jusoff \\ Yale University, School of Forestry \& Environmental Studies \\ 205 Prospect St, New Haven, CT 06511, USA \\ Tel: 20-4-321-384 E- mail: jusoff.kamaruzaman@yale.edu
}

\begin{abstract}
This research is focuses on the practice of risk management (RM) in Client's organization and aims to identify the level of awareness among construction professionals towards risk management and to examine the policy undertaken when dealing with risks in a construction project. Apart from that, it also aims to identify the problems and challenges for the implementation of risk management in Klang Valley, Malaysia. Questionnaire survey and interviews were carried out in order to obtain a better view on the implementation of risk management in the Malaysian construction industry. It was found that construction professional especially those who are working in client's organisation are slowly accepting risk management as a management tool that will help in managing a construction project effectively and successfully. Based on the findings of the questionnaires and interviews there are a number of construction professionals who know about risk management and who have attended training and some of them have even practice risk management in their organizations. At least, it has been proven that there are organizations that have implemented risk management in their operations although this is only on a small scale. It can be concluded that risk management still has a long way to go in order to be accepted and recognized in the Malaysian construction industry.
\end{abstract}

Keywords: Risk management, Client, Construction industry, Practice, Malaysia

\section{Introduction}

According to Mills: "The construction industry is one of the most dynamic, risky, and challenging businesses" (2001, p. 245). As any other major sectors, the construction industry is exposed to a lot of predictable and unpredictable risks. Among the risks faced by the construction industry are political risk, economic risk, technology risk and social risk. Mills (2001) suggested that risk in every construction project can be assumed by another party and this is supported by Hartman, 1996 (as cited in Mills, 2001), that in determining whether a risk should be transferred to the other parties, the receiving party must have both the competence to access the risk and the expertise to deal with the risk and it is very important for both parties to have a similar understanding of the risks. Mills, (2001) also stressed that risk management plays an important role in the decision making process in a construction project and it can affect productivity, performance, quality and the budget of a construction project.

The Construction industry is among of the industries that plays an important role in our country's economic growth. According to Market Watch 2006-Construction Industry, the Malaysian construction industry is generally divided into two areas. First, is the general construction, which comprises residential construction, non-residential construction and civil engineering construction, meanwhile the second area deals with special trade works, which comprises activities of metal works, electrical works, plumbing, sewerage and sanitary works, refrigeration and air conditioning works, painting works, carpentry, tiling and flooring works and glasswork. Although it accounts for less than 5 percent of the GDP, the construction industry is a strong growth push because of its extensive linkages with the other economic sectors (CIDB, 2006). No doubt, the construction industry is among of the important contributor to Malaysia's growth with activities ranging from constructing building, roads, electricity or other transmission lines or towers, pipelines, oil refinery to other specific civil engineering projects (CIDB, 2006). 
According to The Industry Issue-Construction by Bumiputera Commerce Bhd., the implementation of construction projects under the Ninth Malaysia Plan (9MP) is expected to provide some impetus for growth in the construction sector. The report also mentioned that, under the 9MP which will takes a period from 2006 to 2010, the main thrust of the 9MP is on the development of human capital and the services industry and this is good indication that there will be more construction and upgrades of education centres, hospitals and tourist destinations as well as improvement of infrastructure facilities such as roads and bridges. Furthermore, the 9MP will also make an effort in reducing the Government's budget deficit through exercising greater fiscal discipline or prudence to ensure that maximum benefits are obtained when selecting and implementing projects under the 9MP. However, as reported in the report, due to limited resources, new projects that will be considered for the 9MP are projects that will generate multiple benefits for the nation and among the criteria used will be human friendly projects and emphasis will be given to improve road safety and providing convenience for road users and projects which can save travelling cost and time which includes construction and upgrading of roads to overcome traffic congestion in town centres as well as in new growth areas.

The aims of this research are to identify the implementation procedure and policy of risk management and to examine the barriers and challenges to the implementation of risk management in a construction project from the Client's perspective.

\section{Risk management awareness in client's organization}

According to Flanagan and Norman (1993) the construction industry participants are heterogeneous which among of them are client, consultants and contractors that have different roles and task to be performed. Flanagan and Norman (1993) further explained that the client could easily see the relevance of risk management when making the decision to initiates a construction project and any decision and investment made in a project must therefore provide a risk/return profile which is competitive with the best that the financial market can provide. Besides client, other parties in the construction team such as consultants, contractors, subcontractors and supplier are also exposed with a lot of risks. This statement is supported by Sawczuk (1996), who he stressed that no matter how small or simple the project is, it still can go wrong, as soon as the two parties; the client and the contractor have signed a contract, they have taken onboard the risks. In the Malaysian construction industry, risk management is one of the new management concepts. It will take a long time to be fully accepted by the participants in this industry. Most of them are reluctant to change, they are still comfortable with their traditional culture in doing their job without realizing that this new concept will make their job easier. Apart from that, the awareness among the Malaysian construction industry's participants is still low. However, no one can deny that there are the companies in this industry which practice risk management in their daily operation. But, from the early observation we can only see this culture in big companies which have a very good reputation, strong financial standing and which are involved in major projects.

\section{Method and data analysis}

Following a literature review research on risk management success, data were also gathered from the questionnaire surveys on Clients who have implemented the risk management process. A total of 27 companies operated in Klang Valley, Malaysia, responded to the questionnaire. Respondents were asked to fill a questionnaire. They may or may not be fully conversant about risk management or the policy and procedure and its implementation in its entirety. This is more likely to be so in the case of respondents who represented companies that do not have risk management policy and procedure already in place.

For this research, Clients from the public and private sectors were chosen due to their heavy involvement and their important role in a decision making for any matter arising in a project. Apart from that, risk management is one of the most important management tools for a Client when making a decision to commission a construction project. The Questionnaire comprised the following sections:

Section A: Respondents Particulars

Section B: Level of Awareness and Perception on Risk Management

Section C: Implementation and Practice of Risk Management in an Organization

Section D: Barriers and Challenges for the Implementation of Risk Management

It was found that $48.1 \%$ of the respondents were trained as civil and structural engineers, 22.2 per cent are were graduates of quantity surveying, 14.8 per cent were architects, and another 14.8 per cent were made up of individuals from other professional fields (Table 1).

\subsection{Section A: Respondents' Particulars}

\subsubsection{Education Background (Table 2)}

Table 2 shows that a large number $(63 \%)$ of the respondents were degree holders and the rest were master or degree holders $(18.5 \%)$ respectively and diploma holders $(18.5 \%)$. 


\subsubsection{Company Profile}

\section{(1) Years in Operation and Number of Employees}

The descriptive statistics on how long the companies have been in operation and their number of employees are as stated in Table 3.

The mean number of years the companies have been in operation is 13.3 years, but the standard deviation (S.D) of $8.853(\mathrm{C} . \mathrm{V}=66.6 \%)$ is large, implying that the mean does not represent the majority of the companies. The variation between individual companies in term of years of operation is very large. Therefore, this research is of the view that the median value of 11.0 years represents a more accurate indication of how long the majority of the companies have been in operation.

In terms of the number of employees, a few companies with relatively a bigger number of employees appear to dominate the sample. The mean number of workers, which is 406.5 , has an extremely large S.D. of 1378.197 or a C.V. of 390 per cent. This implies that the mean does not represent the majority of the companies. Therefore, this research will refer to the median value of 55.0 whenever the issue of how many employees the companies under study have. That is, half of the companies have less than 55 employees each and half have more than 55 employees each. Despite the less than normal distribution of the companies with respect to years in operation and number of employees as discussed before, the result of the survey would still be useful to the specific objectives of the study. However, risk management is an issue equally important in successful project implementation regardless of whether a company is new or old, big or small.

\section{(2) Sector of Project Involvement}

As shown in Table 4, more than three-quarters (77.8\%) of the companies are involved in private sector projects with 18.5 per cent coming from both the private and public sectors. Only 3.7 percent of the companies are involved totally with public sector projects. (Table 4)

(3) Type of Construction Projects

It was found that $(63 \%)$ per cent of the respondents were involved are in the construction of commercial office buildings. $18.5 \%$ of the companies are involved in civil engineering projects, $14.8 \%$ per cent in public infrastructure projects and 7.4 per cent each in industrial and oil \& gas projects. It can be concluded that most of the companies are involved in more than one line of construction. (Table 5)

\subsection{Section B: Awareness and Perception towards Risk Management}

\subsubsection{Level of Awareness}

This study gauges the levels of awareness of respondents towards risk management.

\section{(1) Understanding Risk Management}

Table 6 shows that the largest proportion (44.4\%) of the respondents heard about risk management only occasionally. That is, risk management is certainly not a term vocabulary they are familiar with, while only 29.6 per cent have heard and attended trainings on it. 14.8 percent are practicing risk management in their job and (11.1\%) per cent have not heard about it at all. (Table 5)

\section{(2) Value of Risk Management}

Only 14.8 per cent of the respondents are practicing risk management on their job where (51.9\%) are of the opinion that risk management can help and add value to the to daily work, especially when working on a project (Table 7). It also shows that (33\%) think that risk management is useful in time of crisis, but only the organisations benefit from it. Many respondents think that risk management is useful either to themselves or to their organizations. This augurs well for the construction industry. 14.8\% apply risk management in their daily work on accounts the grounds of it being in the business plan of the companies account. This equals the percentage of those who claimed to have practiced it on their job as mentioned earlier. (Table 6)

\section{(3) Taking Note of Risk at Work}

Table 8 shows that $(50.0 \%)$ of the respondents take note of risk associated with their work, but do not plan to mitigate the risk. This lends support to the earlier contention that the relatively low percentage of risk management application is, perhaps, due to the fact the companies have not made it a policy. 23 per cent know that the risk management system exists and are aware of the process of risk management. The interpretation of this point is that 14.8 percent go through the process of risk management in their job as it is a policy of the companies and 8.3 percent do it although it is not a

policy. The percentage of respondents that have never taken any note of the risks involved in their projects they are working is miniscule at 3.8. (Table 7)

(4) How Risk Management is Applied 
$40.7 \%$ of the respondents claimed that although departments are communicating risk strategies with one another, it is hazy. 29.6\% confirmed that their companies apply risk management on an ad hoc basis or only during times of crises. 18.5 per cent confirmed that as individual employees, they have used the strategy and process of risk management that is already in place where only 3.7 per cent asserted that there is communication between departments on risk management process. $7.4 \%$ never had applied the risk management process. In a way, this points to the possibility that the majority of respondents are at various stages of readiness to apply risk management, but the companies have not been forthcoming in their overall effort to make it a policy. (Table 8)

(5) Provision of Training on Risk Management. (Table 9)

Table 10 shows that $44.4 \%$ of the respondents claimed that the companies provide very minimum training on risk management, and even if it is so, it is for relevant personnel only. 37.0 per cent said that their companies do not provide such training at all. Those who asserted that their companies provide formal training regularly, including follow-up programmes, account for 11.1 per cent, while those claiming that their employees do plan the training calendar and pursue it actively make up 7.4 per cent.

\subsection{Section C: Perception towards Risk Management}

The perception on each of the above elements is measured/gauged using a 5-point scale from 1 (strongly disagree) to 5 (strongly agree). Table 11 shows the descriptive statistics of the perception scores. (Table 11)

Following the interpretation of a 5-point scale, the respondents, on the average, strongly agree with a mean score of 4.52 that risk affects productivity, performance, and quality and project budget. Although not explicitly stated, the effect of risk on project implementation has to be negative in nature. The respondents also agree that risk management is suitable for projects with certain characteristics (e.g. projects which involve new technology, multiple participants, unstable political conditions, etc.) with a mean score of 4.48. The respondents agreed that risk management should be continuous from start to finish for a project which has a mean score of 4.26 and that risk management with a mean score of 3.67 is required for all projects in descending order of agreement. The respondents were not sure whether the construction industry has a very good reputation in coping with risk (mean score $=3.04$ ). They are also not quite sure whether the implementation of risk management increases operational cost (mean score $=3.48$ ).

\subsubsection{Risk management policy and implementation procedure}

The policy of the companies on the implementation of risk management is gauged from the respondents' response on several questions. The respondents' response will indicate whether the companies do have a credible risk management policy in place. The first indication that a company has a specific policy on risk management implementation is whether it has issued a formal statement about it. Table 12 shows that 18.5 per cent of the respondents confirmed that their companies have issued such a statement. 18.5 per cent of the companies have a risk management strategy and process in place. 4.8 per cent of the respondents have actually been practicing risk management on the job. Only one-fifth of the companies have a risk management policy officially in use. (Table 11)

On the other hand, 34.6 per cent of the respondents asserted that their companies have an identifiable and effective risk management framework in place. Having a risk management framework, even an effective one, does not necessarily mean having a policy per se. Indeed, only 23.1 per cent of the respondents said their companies have separate departments handling risk management. All evidence points to the fact that the seriousness with which companies place emphasis on risk management has not gone to the extent of incorporating it as a company policy. Nevertheless, 34.8 per cent of the respondents claimed that all their projects are subjected to risk management process, while another 34.8 per cent asserted that their companies only carry out risk management on infrastructure projects.

For companies with formal statement on their risk management policy, it was found that 80.0 per cent have policy goals, policy objectives, policy strategies and 80.0 per cent have performance indicators. Looking at these percentage figures, it can be concluded that each company that has risk management policy incorporates all the four elements in its policy. With 18.5 per cent of the companies having issued formal statements on their risk management policies, and out of these, 80.0 per cent have been incorporating all the four elements in its risk management, the percentage of companies that have credible policies on their risk management works out to 14.8 per cent. This percentage figure is similar to that of respondents who have applied risk management in their work because it is in the business plan of their companies. At which stage of a project do organizations begin their risk management undertaking? Feasibility study stage appears to be slightly preferred over other stages, followed by the conceptual/ schematic design stage with $24 \%$, the inception/project briefing stage, detailed design stage, and construction stage with 20.8 per cent of the companies. The various percentages imply that there are a number of companies that initiate risk management activities at more than one stage. This could be project-specific.

\subsubsection{Implementation Procedure}


Twenty-two percent (22.2\%) of the respondents confirmed that their companies have specific processes of identifying risk associated with a project. This is about the same figure as those who claimed their companies have risk management policies and procedures in place. That is, if the companies have a policy and procedure of risk management, they would certainly have a method of identifying the risk associated with a project. Thus, the response of the respondents on this issue is highly consistent. For those who asserted that their companies have specific processes of identifying risk, 80.0 per cent identify it as risk identification process, 80.0 per cent as risk analysis and 66.7 per cent as risk/response control. It is apparent that many of these companies incorporate more than one specific process of identifying risk. Through these risk identification processes, 83.3 per cent of the companies assess the probability and impact of the risk on their projects, 83.3 per cent determine what control measures to implement and 83.3 per cent review the degree of success of the control measures implemented.

$18.5 \%$ of the respondents indicated that their companies have used the service of risk analysis/management consultant. Looking at this percentage figure one is inclined to suspect that the companies concerned are those that have implemented risk management, in particular those that have policy and procedure in place. The service could have been for the purpose of establishing and making the risk management procedure operational, including follow-up evaluations. (Table 12)

50.0 per cent claimed that they have adequate processes of reporting, reviewing, monitoring and recording every on-going risk management activity. 83.3 per cent said that their management reviews the performance of each risk management activity, 80.0 per cent at every completion of project; 75.0 per cent half way through each project; 80.0 per cent at any time deemed necessary. For those who said their companies have risk management standards and procedures, 80.0 per cent claimed that their senior management endorses the document. Eighty per cent said that they are easy to understand; 83.3 per cent thought that it is easy to apply; 80.0 per cent considered the document up to-date; and 66.7 per cent said that it is available to all staff. $92.3 \%$ considered the additional cost and time expended in evaluating risk as contingencies. In this context, this is no different than what is generally adopted by construction companies that do not practice risk management.

\subsection{Section D: Barriers and challenges in implementation}

The barriers in implementing risk management are expected to be in the areas of expertise, cooperation among team members, guideline, and resistance from management as well as staff. Table 14 shows the percentage of respondents that perceive companies are facing problems according to problem areas. $81.5 \%$ of the respondents believe that they lack knowledge on risk management. 14.8 per cent of them apply risk management in their job and in order to apply risk management in their job they have to be conversant in it. Now, when 14.8 per cent said they do not lack knowledge on risk management, they were being consistent in their perception, and this augurs well for the overall reliability of the information obtained from the survey. (Table 13) (Table 14)

Sixty-three per cent of the respondents thought that the companies lacked expertise to lead the risk management team/department. $63.0 \%$ respondents confirmed that there is no guideline on the standard procedure of managing risk and that the management is resistant to the idea. There are other problems facing the implementation of risk management in the companies according to the respondents. $63.0 \%$ do not think that there were lack of cooperation and commitment among construction team members. $29.6 \%$ thought that there was resistant to risk management implementation from the staff.

The above statistics clearly point to the respondents' inclination of placing the "blame" for any weakness in the implementation of risk management on their companies on top management more than on themselves. Take the case of resistance to implementation: it was the management rather than the staff that who are resistant to it (63.0\% against $29.6 \%$ ). This tendency on the part of the respondents is also evident when 63.0 per cent said that their companies

lacked expertise to lead their risk management teams/departments, while 63.0 per cent claimed there were no guidelines on the standard procedure of managing risk.

This research found that the majority of the respondents attribute the problem of risk management implementation to the top management. They suggested that top management should provide training to develop expertise and come up with a workable guideline, or at least make an initiative to that effect. The respondents admitted that they lacked knowledge on risk management but part of the blame was still attributable to the top management if the companies do not invest enough to train their staff on risk management.

\subsubsection{Ways of Promoting Risk Management in the Construction Industry}

Table 15 provides an insight into what the respondents think could promote risk management strategies in the construction industry. (Table 15)

All of the respondents reiterated that companies should provide training and seminars on risk management, presumably at least to all those managing projects. They also believed that new staff being employed in a construction company 
should possess sufficient knowledge on risk management, if not the operational aspects of it, by suggesting that universities/colleges offer courses and programmes on risk management. 96.3 per cent of the respondents suggested the setting up of separate risk management/department in their companies that implying risk management is essential for companies involved in construction projects. Fourteen percent $(14.8 \%)$ of the companies confirmed that they should have risk management policy and procedure in place, most do not have a specific unit/department for it. $88.9 \%$ of the respondents confirmed that the Government should introduce a standard of risk management process and agreed that the government must enforce a statutory requirement in order to promote risk management in the construction industry.

\subsubsection{Who Should Promote Risk Management}

Table 16 shows that $96 \%$ per cent of the respondents are in favor of their own management/companies taking up the effort where as 92.6 per cent confirmed that professional bodies such as Construction Industry Development Board Malaysia, Board of Architects, Board of Quantity Surveyor and 88.9 per cent confirmed that the government should do it. In conclusion, the majority of the respondents feel very strongly that the implementation of risk management should be promoted by all who have a direct interest in the construction industry, including the government. (Table 16)

\section{Conclusion}

The construction industry is among of the industries which are exposed to a lot of predictable and unpredictable risks that may have a greater impact on the productivity, performance, quality and the budget of the project. Therefore, in order to ensure the successful of the project, there should be a proper and systematic risk management strategy in place in order to manage the risk in the most efficient manner. Based on the findings of the questionnaires there are a number of clients who know about risk management and who have attended training and some of them have even practice risk management in their organizations. At least, it's been proven that there are organizations that have implemented risk management in their operations although this is only on a small scale. Although the survey indicated the low level of awareness of risk management in the Clients' organization, their perception towards risk management is very encouraging. Most of them agreed that risk can affect productivity, performance, quality and the project budget. The respondents also agreed that risk management is suitable to be implemented in a construction project with certain characteristics for example project which employ new technology. Earlier observations show that majority of the respondents were unaware about risk management, but when it comes to their perception towards risk management there was a positive feedback. This new concept will eventually become more acceptable and there is a brighter future to be implemented in this industry.

\section{References}

Flanagan, R. \& Norman, G., (1997) Risk Management and Construction. Blackwell Science.

Mills, A. A Systematic Approach to Risk Management for Construction. Retrieved 15 October 2006 from http://www.emerald-library.com/ft.

Swaczuk, B (1996) Risk Avoidance for the Building team, E \& FN, Spon, London.

Table 1. Distribution of Respondents by Professional Background

\begin{tabular}{|l|c|c|}
\hline \multicolumn{1}{|c|}{ Professional Background } & No. of Respondents & Percentage (\%) \\
\hline Architecture & 4 & 14.8 \\
\hline Civil \& Structured Engineering & 13 & 48.1 \\
\hline Quantity Surveying & 6 & 22.2 \\
\hline \hline Others & 4 & 14.8 \\
\hline
\end{tabular}

Table 2. Distribution of Respondents by Highest Education Background

\begin{tabular}{|l|c|c|}
\hline \multicolumn{1}{|c|}{ Educational Qualification } & No. of Respondents & Percentage (\%) \\
\hline \hline Diploma & 5 & 18.5 \\
\hline \hline Degree & 17 & 63 \\
\hline \hline Master & 5 & 18.5 \\
\hline
\end{tabular}


Table 3. Descriptive Statistics on Years in Operation and Number of Employees

\begin{tabular}{|l|c||c|c|}
\hline \multicolumn{1}{|c|}{ Item } & Mean & Median & S.D. \\
\hline \hline Years in operation & 13.3 & 11.0 & 8.853 \\
\hline Number of employees & 406.6 & 55.0 & 1378.197 \\
\hline
\end{tabular}

Table 4. Distribution of Companies by Sector of Project Involvement

\begin{tabular}{|l|c|c|}
\hline \multicolumn{1}{|c|}{ Sector Involved } & No. of Respondents & Percentage (\%) \\
\hline \hline Public & 1 & 3.7 \\
\hline \hline Private & 21 & 77.8 \\
\hline \hline Both & 5 & 18.5 \\
\hline
\end{tabular}

Table 5. Distribution of Companies by Type of Construction Project

\begin{tabular}{|l|c|c|}
\hline \multicolumn{1}{|c|}{ Types } & No. of Respondents & Percentage (\%) \\
\hline \hline Public \& Infrastructure & 4 & 14.8 \\
\hline Residential & 27 & 100 \\
\hline Commercial & 17 & 63 \\
\hline Civil Engineering & 5 & 18.5 \\
\hline \hline Industrial & 2 & 7.4 \\
\hline Oil \& Gas & 2 & 7.4 \\
\hline
\end{tabular}

Table 6. Distribution of Respondents by Understanding of Risk Management

\begin{tabular}{|l|c|c|}
\hline \multicolumn{1}{|c|}{ Understanding on Risk Management } & No. of Respondents & Percentage (\%) \\
\hline \hline Never heard of it & 3 & 11.1 \\
\hline \hline Heard Occasionally & 12 & 44.4 \\
\hline \hline Heard and Attend Training & 8 & 29.6 \\
\hline \hline Practice RM & 4 & 14.8 \\
\hline
\end{tabular}

Table 7. Distribution of Respondents on the Value of Risk Management

\begin{tabular}{|l|c|c|}
\hline \multicolumn{1}{|c|}{ Value of Risk Management } & No. of Respondents & Percentage (\%) \\
\hline Useful in time of crisis & 9 & 33.3 \\
\hline Add value to daily work & 14 & 51.9 \\
\hline Applied in daily work & 4 & 14.8 \\
\hline
\end{tabular}


Table 8: Distribution of Respondents by Category of Risk Note Taking

\begin{tabular}{|l|c|c|}
\hline \multicolumn{1}{|c|}{ Risk Note Taking } & No. of Respondents & Percentage (\%) \\
\hline \hline Never take note & 2 & 3.8 \\
\hline \hline Take note only & 13 & 50 \\
\hline \hline Take note only when asked & 6 & 23.1 \\
\hline \hline Take note of all process & 6 & 23.1 \\
\hline
\end{tabular}

Table 9. Distribution of Respondents by How Risk Management Is Applied

\begin{tabular}{|l|c|c|}
\hline \multicolumn{1}{|c|}{ How RM Being Applied } & No. of Respondents & Percentage (\%) \\
\hline \hline Ad hoc & 8 & 29.6 \\
\hline \hline Communicated between department but not clear & 11 & 40.7 \\
\hline \hline Communicated between department & 1 & 3.7 \\
\hline \hline RM in place & 5 & 18.5 \\
\hline \hline None & 2 & 7.4 \\
\hline
\end{tabular}

Table 10. Distribution of Respondents by Companies Providing Risk management Training

\begin{tabular}{|l|c|c|}
\hline \multicolumn{1}{|c|}{ Provision of Training } & No. of Respondents & Percentage (\%) \\
\hline \hline None & 10 & 37 \\
\hline \hline Minimum training to relevant personnel & 12 & 44.4 \\
\hline Regular formal training programme & 3 & 11.1 \\
\hline \hline Plan training calendar & 2 & 7.4 \\
\hline
\end{tabular}

Table 11. Descriptive Statistics on Perception on Risk and Risk Management

\begin{tabular}{|l|c|c|c|}
\hline \multicolumn{1}{|c|}{ Statement } & Mean score & Median & S.D. \\
\hline Risk affects productivity, performance, quality and project budget & 4.52 & 5.00 & 0.802 \\
\hline It should be continuous from start to finish & 4.26 & 4.00 & 0.712 \\
\hline It is required for all projects & 3.67 & 4.00 & 1.074 \\
\hline $\begin{array}{l}\text { It is suitable for projects with certain characteristic (e.g. new } \\
\text { technology, multiple participants, unstable political conditions, etc.) }\end{array}$ & 4.48 & 3.00 \\
\hline It increases operational cost & 3.48 & 3.00 & 0.700 \\
\hline Construction industry has a very good reputation in coping with risk. & 3.04 & 3.00 & 1.160 \\
\hline All elements & 3.91 & 3.83 & 0.407 \\
\hline
\end{tabular}


Table 12. Percentage of Respondents by Statement Related to Implementation of Risk Management Policy

\begin{tabular}{|l|c|c|c|}
\hline \multicolumn{1}{|c|}{ Statement } & Yes & No & Not Sure \\
\hline \hline The company has an identifiable and effective risk management framework & 34.6 & 61.5 & 3.8 \\
\hline in place & 23.1 & 76.9 & 0.0 \\
\hline The company has its own risk management department & & & \\
\hline Implementation of Risk Management on projects: & 34.8 & 65.2 & 0.0 \\
All projects & 34.8 & 65.2 & 0.0 \\
Infrastructure projects & 100.0 & 0.0 & 0.0 \\
Other projects & 18.5 & 77.8 & 3.7 \\
\hline The company has issued a formal statement on its risk management policy & & & \\
\hline \hline For those with formal statement of policy, it contains: & 80.0 & 20.0 & 0.0 \\
Goals & 80.0 & 20.0 & 0.0 \\
Objectives & 80.0 & 20.0 & 0.0 \\
Strategies & 80.0 & 20.0 & 0.0 \\
Performance indicators & & & \\
\hline Stage at which organisational risk undertaking begins: & 20.8 & 75.0 & 4.2 \\
Inception/project briefing stage & 24.0 & 72.0 & 4.0 \\
Conceptual/schematic design stage & 26.9 & 69.2 & 3.8 \\
Feasibility study stage & 20.8 & 75.0 & 4.2 \\
Detail design stage & 20.8 & 75.0 & 4.2 \\
Construction stage & 3.7 & 96.3 & 0.0 \\
\hline Other stages & & & \\
\hline
\end{tabular}

Table 13. Percentage of Respondents by Elements of Risk Management Procedure

\begin{tabular}{|c|c|c|c|}
\hline Element & Yes & No & Not Sure \\
\hline $\begin{array}{l}\text { Company has specific processes of identifying risk associated with a } \\
\text { project }\end{array}$ & 22.2 & 77.8 & 0.0 \\
\hline $\begin{array}{l}\text { The specific processes are: } \\
\text { Risk identification } \\
\text { Risk analysis } \\
\text { Risk/response control }\end{array}$ & $\begin{array}{l}80.0 \\
80.0 \\
66.7\end{array}$ & $\begin{array}{l}20.0 \\
20.0 \\
33.3\end{array}$ & $\begin{array}{l}0.0 \\
0.0 \\
0.0\end{array}$ \\
\hline $\begin{array}{l}\text { The above processes are to do the following: } \\
\text { Assessing its probability and impact on a project } \\
\text { Determining what control measures to implement } \\
\text { Reviewing the degree of success of the control measures implemented }\end{array}$ & $\begin{array}{l}83.3 \\
83.3 \\
83.3\end{array}$ & $\begin{array}{l}16.7 \\
16.7 \\
16.7\end{array}$ & $\begin{array}{l}0.0 \\
0.0 \\
0.0\end{array}$ \\
\hline Company has used the service of risk analysis/management consultant & 18.5 & 81.5 & 0.0 \\
\hline $\begin{array}{l}\text { Processes of reporting, reviewing, monitoring and recording every } \\
\text { ongoing risk management activity are adequate }\end{array}$ & 50.0 & 16.7 & 33.3 \\
\hline $\begin{array}{l}\text { Management reviews the performance of each risk management } \\
\text { activity }\end{array}$ & 83.3 & 16.7 & 0.0 \\
\hline $\begin{array}{l}\text { If so, it is at: } \\
\text { Every completion of project } \\
\text { Half way through project } \\
\text { Any time deemed necessary }\end{array}$ & $\begin{array}{l}80.0 \\
75.0 \\
80.0\end{array}$ & $\begin{array}{l}20.0 \\
25.0 \\
20.0\end{array}$ & $\begin{array}{l}0.0 \\
0.0 \\
0.0\end{array}$ \\
\hline $\begin{array}{l}\text { The company's risk management standard and procedure is: } \\
\text { Endorsed at the senior management level } \\
\text { Easy to understand } \\
\text { Easy to apply } \\
\text { Up-to-date } \\
\text { Available to all staff }\end{array}$ & $\begin{array}{l}80.0 \\
80.0 \\
83.3 \\
80.0 \\
66.7\end{array}$ & $\begin{array}{l}20.0 \\
20.0 \\
16.7 \\
20.0 \\
33.3\end{array}$ & $\begin{array}{l}0.0 \\
0.0 \\
0.0 \\
0.0 \\
0.0\end{array}$ \\
\hline $\begin{array}{l}\text { In evaluating risk, the additional cost and time is considered as } \\
\text { contingencies }\end{array}$ & 92.3 & 7.7 & 0.0 \\
\hline
\end{tabular}


Table 14. Percentage of Respondents Opinion on Problem Area

\begin{tabular}{|l|c||c|c|}
\hline \multicolumn{1}{|c|}{ Problem } & Yes & No & Not Sure \\
\hline \hline Lack of knowledge on risk management & 81.5 & 14.8 & 3.7 \\
\hline $\begin{array}{l}\text { Lack of expertise to lead the risk management } \\
\text { team/department }\end{array}$ & 63.0 & 25.9 & 11.1 \\
\hline $\begin{array}{l}\text { Lack of cooperation and commitment among } \\
\text { construction team members }\end{array}$ & 37.0 & 63.0 & 0.0 \\
\hline $\begin{array}{l}\text { There is no guideline on the standard procedure of } \\
\text { managing risk }\end{array}$ & 63.0 & 25.9 & 11.1 \\
\hline Resistance from the management & 63.0 & 33.3 & 0.0 \\
\hline \hline Resistance from the staff & 29.6 & 66.7 & 3.7 \\
\hline \hline Other problems & 96.3 & 3.7 & 0.0 \\
\hline
\end{tabular}

Table 15. Percentage of Respondents by Ways to Promote Risk Management in Construction Industry

\begin{tabular}{|l|c|c|c|}
\hline \multicolumn{1}{|c|}{ Ways to Promote Risk Management } & Yes & No & Not Sure \\
\hline Provide training and seminar on risk management & 100.0 & 0.0 & 0.0 \\
\hline $\begin{array}{l}\text { The management should support the setting up a risk } \\
\text { management unit/department }\end{array}$ & 96.3 & 3.7 & 0.0 \\
\hline $\begin{array}{l}\text { Introduce standard on risk management by } \\
\text { government or any other agencies }\end{array}$ & 88.9 & 7.4 & 3.7 \\
\hline $\begin{array}{l}\text { Introduce courses and programmes related to risk } \\
\text { management in colleges/universities }\end{array}$ & 100.0 & 0.0 & 0.0 \\
\hline Enforce a statutory requirement & 85.2 & 14.8 & 0.0 \\
\hline
\end{tabular}

Table 16. Percentage of Respondents by Who Should Promote Risk Management

\begin{tabular}{|l|c|c|c|}
\hline \multicolumn{1}{|c|}{ Who should promote } & Yes & No & Not Sure \\
\hline \hline Government & 88.9 & 3.7 & 7.4 \\
\hline Management of company & 96.3 & 0.0 & 3.7 \\
\hline $\begin{array}{l}\text { Professional bodies such as CIDB, Board of } \\
\text { Architects, Board of QS, etc. }\end{array}$ & 92.6 & 3.7 & 3.7 \\
\hline
\end{tabular}

